
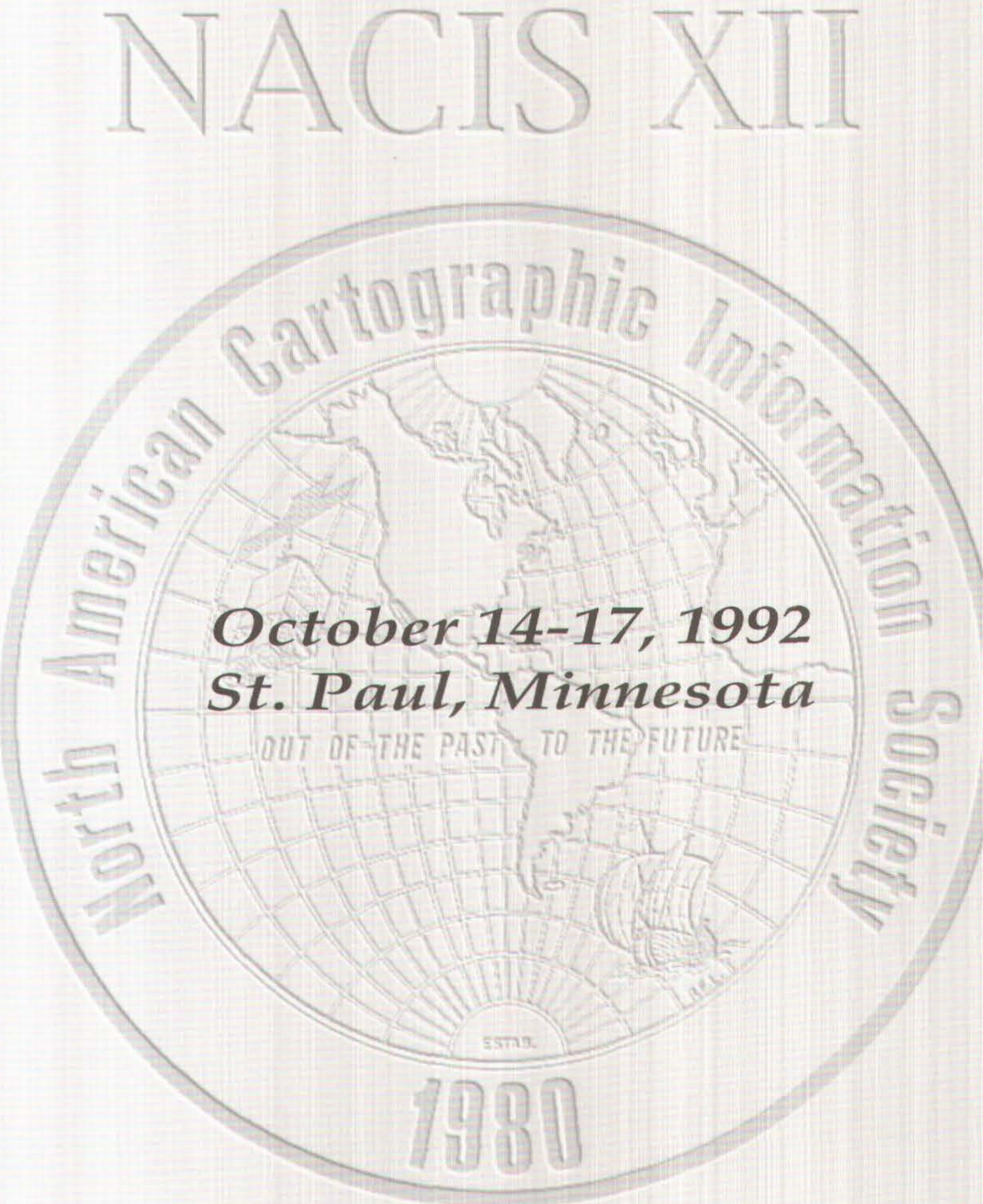
NACIS XII

\section{Conference Schedule}

(Preliminary)

\begin{tabular}{c|c} 
Wednesday Oct. 14 & $\begin{array}{l}1: 30-5: 00 \text { p.m. Technical and } \\
\text { Local Tours } \\
\text { 2:00 p.m. Registration Begins } \\
\text { 2:00 - 5:00 NACIS Board Meeting Department of Transporta- } \\
\text { tion }\end{array}$ \\
$\begin{array}{l}\text {-Riverboat Tour of the Twin Cities Area } \\
\text {--Minnesota Historical Society Map } \\
\text { Collection }\end{array}$
\end{tabular}

7:30 - 8:00 OPENING SESSION Welcome to The Twin Cities Greg Chu

Welcome to NACIS XII Jeff Patton

8:00 - 9:00 Opening Address John Fraser Hart, Professor. Department of Geography, University of Minnesota.

9:00 - 11:00 Opening Exhibits/ Posters (Cash Bar Social)

Thursday, Oct. 15

8:30 - 10:00 a.m. SESSION A

"Child Development and Cartographic Education" Papers by Psychologists and Cartographers on how. children develop spatial awareness and the implications for geographic and cartographic education. Organizer - Henry W. Castner.

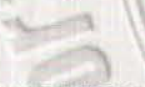

\section{CONCURRENT SESSION B}

"Federal Mapping Agencies" Organizers - Roh Boiton and Charles Harrington.

10:00 - 10:30 Break

10:30 - 12:00 SESSIONC

"The Development of Spatial

Awareness" A panel discussion of Session A's papers on this topic. Organizers - Herbert Pick and Henry Castner.
CONCURRENT SESSION D

"Electronic Atlases and Digital

Data Bases" Organizer - Thomas

Hodler.

\section{2:00 - 1:00 Lunch Break}

\section{ANNUAL BANQUET} 6:30 - 7:30 Cash Bar

8:30 - 9:00 President's Remarks Jack Dodd

9:00-10:00 Banquet Address Arthur H. Robinson, Professor Emeritus, Deptartment of Geography University of Wisconsin-Madison.

Friday, Oct. 16

8:30 - 10:00 a.m. SESSION E "Software Use in Cartographic the Small Lab" Organizers - Joseph Stoll and Donna Schenstrom.

\section{CONCURRENT SESSION FU} "Communication and Cognition in Mapping" Organizers - Scott Fruendschuh, Riley Jacobs and Margaret Pearce.

10:00 - 10:30 Break

10:30 - 12:00 SESSION G

"Interactive Videodisc Mapping

Project" Organizers-Sona Andrews,

Chris Baruth, David Tilton and Yvonne

Bode: sรTa. Production with an Emphasis on
12:00 - 2:00 p.m. Lunch Buffet and Annual Business Meeting

2:00 - 4:00 SESSION I

"Cartographic Education" A panel discussion of current trends in university cartographic education. Panel includes representatives from academia, the public sector, and commercial cartographic firms. Organizer - Keith Rice.

Concurrent SESSION

"Map Librarians and Digital

Data" Organizers - Patrick

McGlamery, Jim Minton and Johnny Sutherland.

\section{4:00-6:00 NACIS Board Meeting}

Saturday, Oct. 17

\section{Workshops}

Buses leave at 8:30 a.m. for workshops at the University of Minnesota.

9:00-12:00 Map Producition and Design using Corel Draw - Greg Chu (Note: This is a morning session only. If there is enough interest, it may be repeated in the afternoon.).

\section{9:00-4:30 Macintosh Animation}

Michael Peterson, Riley Jacobs, John

Krygier, Catherine Reeves, David Tilton.

-ty

9:00-4:30IBM-Based Animation Phil Gershmel.

Social events for non-workshop participants:

8:30-12:00 Visit to the Megamall

"Mall of America"

1:30-? Treasure Island Casino

(Casino will provide shuttle).

5:00 Wine and Cheese Reception University of Minnesota Map Library \& Cartography Laboratory.
CONCURRENT SESSION H

"Map Librarians Speak to Geographers and Cartographers: What We Can Do For You and How to Get What You Need From Us" A series of brief presentations followed by an extended panel discussion. OrganizerNancy Kandoian. 


\section{Workshops}

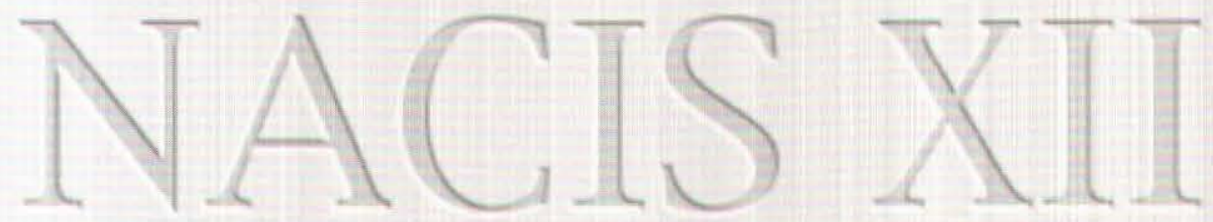

\section{IBM-based Map Design and Production}

Saturday, 10/17/92 9:00-12:00 noon

Cost $\$ 50$ (\$100 for nonregistered participants, $\$ 35$ for registered students)

You will receive hands-on training in creating maps using CorelDraw! 3.0. The differences between traditional and computer-assisted design methods will be analyzed. Participants will receive a set of public domain base map files to take with them.

Software and Instructor:

Corel Draw! 3.0 - Gregory Chu, Director, cartography Lab, University of Minnesota.

NOTE: This workshop may be offered again in the afternoon depending on the response.

IBM-based Animation Saturday, $10 / 17 / 92$
$9: 00-4: 30$

Cost $\$ 70$ ( $\$ 125$ for nonregistered participants, $\$ 45$ for registered students)

You will learn the basic principles of designing and producing dynamic animated maps for broadcast purposes. The workshop will be conducted with a combination of lectures, explanations, demonstrations, and hands-on exercises. There will be opportunities for questions.

Software and Instructor: Autodesk Animator - Professor Rhilip J. Gershmel, University of Minnesota.

Macintosh Animation

Saturday, 10/17/92

9:00-4:00

Cost: $\$ 75$ ( $\$ 125$ for nonregistered participants, $\$ 45$ for registered students)

You will explore the basic principles and techniques of cartographic animation using a variety of software demenstrated by five different instructors. Twenty five Macintosh Ilci computers will be available so that workshop attendees will have hands-on experience in creating their own animations.

Software and Instructors: MacChoro II, Adobe Premiere and QuickTime - Michael Peterson, University of Nebraska at Omaha.

Hypercard - Riley Jacobs, University of Nebraska at Omaha. Macromind Director - John Krygier and Catherine Reeves, Pennsylvania State University; David Tilton, University of Wisconsin-Milwaukee. 


\section{FEATURED PAPERS}

Each issue of Cartographic Perspectives includes featured papers, which are refereed articles reporting original work of interest to NACIS' diverse membership. Papers ranging from theoretical to applied topics are welcome.

Prospective authors are encouraged to submit manuscripts to the Editor or to the Chairperson of the NACIS Editorial Board. Papers may also be solicited from presenters at the annual meeting and from other sources. Papers should be prepared exclusively for publication in $C P$, with no major portion previously published elsewhere. All contributions will be reviewed by the Editorial Board, whose members will advise the Editor as to whether a manuscript is appropriate for publication. Final publication decisions rest with the Editor, who reserves the right to make editorial changes to ensure clarity and consistency of style.

\section{REVIEWS}

Book reviews, map reviews, and mapping software reviews are welcome. The Editor will solicit reviews for artifacts received from publishers. Prospective reviewers are also invited to contact the Editor directly.

\section{FUGITIVE CARTOGRAPHIC LITERATURE}

Information of interest to map makers, librarians, and educators appears in diverse publications. We invite synopses of reviews, news, and papers found in outlets not usually associated with cartography, map librarianship, or geography.

\section{TECHNICAL GUIDELINES FOR SUBMISSION}

Cartographic Perspectives is designed and produced in a microcomputer environment. Therefore, contributions to $\mathrm{CP}$ should be submitted in digital form on 3.5 " diskettes. Please send a paper copy along with the disk, in case it is damaged in transit.

Text documents processed with Macintosh software such as WriteNow, WordPerfect, Word, and MacWrite are preferred, as well as documents generated on IBM PCs and compatibles using WordPerfect or Word. ASCII text files are also acceptable.

PostScript graphics generated with Adobe Illustrator or Aldus FreeHand for the Macintosh or Corel Systems' Corel Draw for DOS computers are preferred, but generic PICT or TIFF format graphics files are usually compatible as well.

For those lacking access to microcomputers, typed submissions will be cheerfully accepted. Manually produced graphics should be no larger than 11 by 17 inches, designed for scanning at 600 dpi resolution (avoid finegrained tint screens). Continuoustone photographs will also be scanned.

Literature cited should conform to the Chicago Manual of Style, 13th ed., University of Chicago Press, Chapter 16, style "B". Examples of the correct citation form appear in the feature articles of this issue.

Submissions may be sent to: Sona Karentz Andrews, Department of Geography, 208 Sabin Hall, 3413 N. Downer Avenue, University of Wisconsin-Milwaukee, Milwaukee, WI 53211; (414) 229-4872, fax (414) 229-3981; email: sona@csd4.csd.uwm.edu.
Cartographic Perspectives EDITORIAL BOARD

Michael Peterson

University of Nebraska-

Omaha

Charles Rader

Michigan State University

Nancy Ryckman

University of North Carolina-

Greensboro

Donna Schenstrom

University of WisconsinMilwaukee

Marsha Selmer

University of Illinois-Chicago

\section{COLOPHON}

This document was desktoppublished at the Department of Geography, University of Wisconsin-Milwaukee, using Macintosh IIci computers. Word processing was accomplished primarily with Word 4.0 ; page layout with PageMaker 4.2. Graphics not rendered with Aldus FreeHand 3.1 were scanned from paper originals. The PageMaker document was output by an Agfa ProSet 9800 at $2400 \mathrm{dpi}$. The bulletin was printed by offset lithography on Warren Patina 70\# text stock. Text type is set in Palatino, a face designed by Herman Zapf. The issue number dictated black as the cover color. 